\title{
Kombinari Ekstrak Daun Tapak Dara (Catharanthus roseus L.) dan Daun Jambu Air Semarang (Syzygium samarangense (Blum.) Merr. \& Perry.) Varietas Camplong dalam Menekan Intensitas Serangan Serangga Hama pada Tanaman Kacang Panjang (Vigna sinensis L.)
}

\author{
Dea Yullvita Ningrum', Sonja. V. T. Lumowa', Sri Purwati' \\ ${ }^{1}$ Fakultas Keguruan dan Ilmu Pendidikan Universitas Mulawarman, Samarinda, Indonesia, \\ deayullvita@gmail.com \\ ${ }^{2}$ Fakultas Keguruan dan Ilmu Pendidikan Universitas Mulawarman, Samarinda, Indonesia, \\ verasonja@yahoo.com \\ ${ }^{3}$ Fakultas Keguruan dan IImu Pendidikan Universitas Mulawarman, Samarinda, Indonesia, \\ purwati7504@gmail.com
}

\begin{abstract}
This study aims to determine the effect of the combination of tapak dara leaf extract and water guava leaf extract on the intensity of insect pests on long bean plants. This type of research is an experimental research conducted in the agricultural land of Kampung Sei. Fatimah, Nunukan District, Nunukan Regency, North Kalimantan. Using a randomized block design (RBD) with 5 treatments, namely $T_{0}$ (control), $T_{1}(25 \%), T_{2}(40 \%), T_{3}(55 \%)$ and $T_{4}$ (70\%) with 5 replications. The results of data analysis give results 168.12> $F_{\text {table }}$ significant level 1\% (4.77). Based on the data analysis, there is a very significant effect on the combination of tapak dara leaf extract and Semarang water guava leaf on the intensity of insect pest attack on long bean plants
\end{abstract}

Key words: combination, tapak dara leaves, Semarang water guava leaves, pests, long beans.

\begin{abstract}
Abstrak Penelitian ini bertujuan untuk mengetahui pengaruh kombinasi ekstrak daun tapak dara dan daun jambu air Semarang terhadap intensitas serangan serangga hama pada tanaman kacang panjang. Jenis penelitian ini adalah penelitian eksperimen yang dilaksanakan di lahan pertanian Kampung Sei. Fatimah, Kecamatan Nunukan, Kabupaten Nunukan, Kalimantan Utara. Menggunakan rancangan acak kelompok (RAK) dengan 5 perlakuan yaitu $T_{0}$ (kontrol), $T_{1}(25 \%)$, $T_{2}$ (40\%), $T_{3}(55 \%)$ dan $T_{4}$ (70\%) dengan 5 ulangan. Hasil analisis data memberikan hasil $168.12>$ $F_{\text {tabel }}$ taraf signifikan $1 \%$ (4.77). Berdasarkan analisis data terdapat pengaruh sangat nyata pada pemberian kombinasi ekstrak daun tapak dara dan daun jambu air Semarang terhadap intensitas serangan serangga hama pada tanaman kacang panjang.
\end{abstract}

Kata kunci : kombinasi, daun tapak dara, daun jambu air, serangga hama, kacang panjang

Dipublikasikan: $\mathrm{XX}-\mathrm{XX}-20 \mathrm{xx}$

Penerbit

Program Studi Pendidikan Biologi, Fakultas Keguruan dan Ilmu Pendidikan, Universitas Mulwarman, Samarinda, Kalimantan Timur, Indonesia

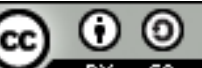

This Jurnal Ilmiah Biosmart (JIBS) is licensed under a CC BY-SA (Creative Commons AttributionShareAlike 4.0 International License) 


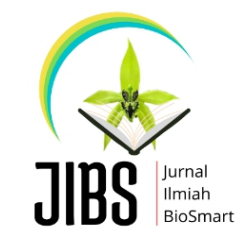

JURNAL ILMIAH BIOSMART (JIBS)

Volume 1, Nomor 1

p-ISSN: 2356-1823

https://jurnal.fkip.unmul.ac.id/index.php/biosmart

\section{PENDAHULUAN}

Negara Indonesia merupakan negara agraris yang memiliki tanah yang subur dan sebagian besar penduduknya memiliki mata pencaharian sebagai petani atau bercocok tanam. Saat ini kebutuhan pangan penduduk tidak hanya diarahkan pada pemenuhan kebutuhan padi (beras) saja, tetapi juga pada pengembangan komoditas hortikultura, termasuk di dalamnya adalah komoditas sayuran. Salah satu komoditas sayuran yang banyak dikonsumsi oleh masyarakat Indonesia adalah tanaman hortikultura yang berupa kacang sayur yaitu kacang panjang.

Potensi dan peranan komoditas kacang sayur, khususnya keluarga (famili) tanaman kacang panjang, kacang buncis, kacang kapri dan kacang kedelai sayur (edamame) dalam pola konsumsi masyarakat Indonesia sangat penting sebagai penyuplai pangan bergizi sumber protein nabati, vitamin dan mineral (Rukmana, 2014).

Kacang panjang (Vigna sinensis L.) merupakan komoditas hortikultura yang banyak dibudidayakan oleh petani. Beberapa kendala dalam meningkatkan produksi kacang panjang yaitu kurangnya minat petani dalam bertaman kacang panjang (bukan sebagai tanaman utama yang dibudiayakan), produktivitas masih rendah, dan harganya yang fluktuatif. Selain kendala tersebut, kendala yang langsung dialami petani yaitu serangan organisme penganggi tanaman (OPT) (Apriyanto dan Bondan, 2014).

Menurut penelitian Soetiarso dan Marpaung (dalam Putri, 2015), menunjukkan bahwa preferensi konsumen rumah tangga terhadap kualitas kacang panjang antara lain memiliki panjang polong yang sedang $(40-60 \mathrm{~cm})$, polong yang renyah dan rasa polong yang manis. Kualitas hasil produksi kacang panjang dapat dilihat dari segi rasa dan kandungan gizi di dalamnya. Rasa yang manis dan kandungan vitamin yang tinggi menjadikan kacang panjang sebagai kmoditas dengan nilai ekonomi yang cukup tinggi.

Berdasarkan data Badan Pusat Statsitik Kabupaten Nunukan (2018) produksi kacang panjang mengalami penurunan dari tahun sebelumnya. Produksi kacang panjang di Nunukan pada tahun 2017 yaitu sebanyak 291,6 ton sedangkan pada tahun 2018 yaitu sebanyaj 186,6 ton. Maka, perkembangan produktivitas kacang panjang di 


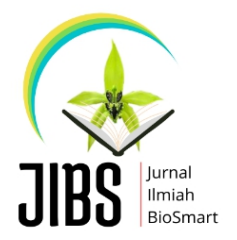

JURNAL ILMIAH BIOSMART (JIBS)

Volume 1, Nomor 1

p-ISSN: 2356-1823

https://jurnal.fkip.unmul.ac.id/index.php/biosmart

Nunukan pada tahun 2018 menurun sebanyak 36\% dari tahun sebelumnya. Hal tersebut salah satunya diakibatkan karena gagal panen yang disebabkan oleh serangan hama pada tanaman kacang panjang.

Menurut Syafitri dan Juslistia dalam Baon (2018) beberapa hama dan penyakit pada tanaman kacang panjang antara lain, ulat grayak (Spodoptera litura), lalat kacang (Ophiomya phaseoli Tryon), ulat penggerek polong (Maruca testulalis), kutu daun (Aphis sp), penyakit antraknosem oenyakit mozaik, penyakit sapu dan layu bakteri.

Sebagian besar para petani melakukan upaya untuk mengendalikan hama pada tanaman kacang panjang dengan cara menggunakan pestisida kimia sintesis. Bersdasarkan hal tersenut, peneliti melakukan observasi dan wawancara pada salah satu petani kacang panjang yang berada di daerah Persemaian, Nunukan. Petani tersebut menggunakan pestisida kimia sintesis yang berupa obat demolish untuk mengendalikan hama pada tanaman kacang panjang. Telah diketahui bahwa pestisida kimia sintesis memiliki dampak yang sangat berbahaya bagi petani maupun orang yang mengkonsumsi tanaman yang menggunakan pestisida kimia tersebut.

Upaya alternatif untuk mengendalikan hama pada tanaman adalah dengan menggunakan pestisida nabati. Lebih dari 1.500 jenis tumbuhan di dunia dapat digunakan sebagai pestisida nabati. Bahan aktif pestisida nabati adalah produk alam yang berasal dari tanaman yang memiliki kelompok metabolit sekunder dan mengandung senyawa bioaktif seperti alkaloid, terpenoid, fenolik dan zati kimia skunder lainnya. Pestisida nabati sangat efektif untuk membasmi organisme penganggu tanaman (OPT) (Glio, 2015).

Pestisida nabati dapat dibuat berupa larutan, hasil perasan, rendaman, ekstrak hasil olahan bagian tanaman, seperti daun, batang, akar dan buah (Tigaw, dkk 2015). Salah satu tanaman yang dapat digunakan sebagai pestisida nabati adalah daun tapak dan daun jambu air Semarang.

Analisis fitokimia terhadap ekstrak daun tapak dara menunjukkan bahwa daun tapak dara mengandung alkaloid, terpenoid, fenol, tanin, saponin, quinin, dan sterol (Kabesh, dkk, 2015 dan Purbosari dan Erika, 2018) dan daun jambu air mengandung senyawa fenolik (Agustina, dkk., 2018). Menurut Wong dan Lai (1996 dalam Agustina, 


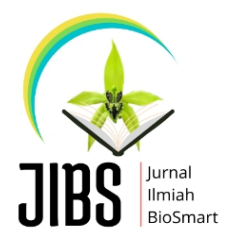

JURNAL ILMIAH BIOSMART (JIBS)

Volume 1, Nomor 1

p-ISSN: 2356-1823

https://jurnal.fkip.unmul.ac.id/index.php/biosmart

dkk., 2018) genus Syzygium mengandung terpenoid dan terpinene dalam jumlah tinggi. Tanin juga ditemukan dalam daun spesies Syzygium samarangense (Okuda, dkk,. 2009 dalam Agustina, dkk., 2018).

Untuk menghindari penyerangan hama pada tanaman kacang panjang, peneliti mencoba membuat pestisida nabati dari kombinasi ekstrak daun tapak dara (Catharanthus roseus L.) dan daun jambu arie Semarang (Syzygium samarangense (Blum.) Merr.\& Perry.) varietas camplong untuk mengendalikan serangan serangga hama pada tanaman kacang panjang (Vigna sinensis L.).

\section{METODE}

Jenis penelitian ini adalah penelitian eksperimen yang bertujuan untuk mengetahui pengaruh perlakuan tertentu dalam kondisi yang terkendalikan dengan menggunakan kombinasi dari ekstrak daun tapak dara dan daun jambu air Semarang varietas camplong terhadap intensitas serangan hama pada tanaman kacang panjang. Teknik pengambilan sampel dalam penelitian ini yaitu Non Random Sample. Metode ini menggunakan kriteria yang telah dipilih oleh peneliti dalam memilih sampel yakni sebanyak 125 tanaman kacang panjang yang sehat dengan tinggi dan jumlah daun yang sama.

Alat dan bahan yang digunakan adalah blender, timbangan digital,saringan, sendok atau spatula, baskom atau ember, pisau, kamera, hand sprayer, sekop, penggaris, cangkul, alat tulis, meteran, bibit kacang panjang, daun tapak dara, daun jambu air semarang varietas camplong, air, tanah, pupuk kandang, deterjen, label, kayu dan tali. Kegiatan selama proses penelitian antara lain, persiapan lahan, pembuatan ekstrak, penanaman, penyemaian, penyiraman, pemasangan ajir, penyiangan, pemupukan dan penanggulangan hama.

Racangan yang digunakan dalam oenelitian ini adalah Rancangan Acak Kelompk (RAK), yanng terdiri dari 5 perlakuan termasuk kontrol dan 5 pengulangan. Kombinasi ekstrak daun tapak dara (Catharanthus roseus L.) dan daun jambu air Semarang (Syzygium samarangense (Blum.) Merr.\& Perry) yang diapliksikan pada sampel tanaman kacang panjang memiliki konsentrasi yang bevrariasi, yaitu konsentrasi $25 \%, 40 \%, 55 \%$, dan $70 \%$. Selain itu, dalam penelitian ini terdapat beberapa 


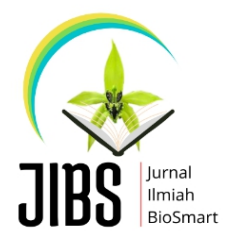

JURNAL ILMIAH BIOSMART (JIBS)

Volume 1, Nomor 1

p-ISSN: 2356-1823

https://jurnal.fkip.unmul.ac.id/index.php/biosmart

sampel tanaman kcang panjang yang tidak diberi kombinasi ekstrak daun tapak dara dan daun jambu air Semarang tetapi hanya diberi air saja (kontrol).

Pengamatan di(alakukan pada umur 11, 18, 25, 32 dan 39 HST dengan menggunakan rumus :

$$
I=\frac{n}{N} \times 100 \%
$$

Keterangan:

$\mathrm{I}=$ Intensitas kerusakan

$\mathrm{n}=$ Jumlah daun yang terserang

$\mathrm{N}=$ Jumlah seluruh daun dalam satu tanaman

Dengan niali skalanya yaitu o (tidak ada serangan hama/ tanaman sehat), kerusakan <

$25 \%$ (serangan hama ringan), kerusakan $25-50 \%$ (serangan hama sedang), kerusakan 50-75\% (serangan hama berat) dan kerusakan > 75\% (serangan hama sangatb berat).

Kemudian data-data yang diperoleh, dianalisis menggunakan sidik ragam Analysis of Variance (ANOVA).

\section{HASIL DAN PEMBAHASAN}

Penelitian ini dilakukan dilahan pertanian yang bertempat di Jalan Sungai Fatimah RT. 20, Kelurahan Nunukan Barat, Kecamatan Nunukan, Kabupaten Nunukan, Kalimantan Utara. Dimana luas area yang digunakan untuk penelitian adalah $(10 \times 10 \mathrm{~m})$ dan $\mathrm{pH}$ tanah berkisar 3,5-4,5 dengan suhu udara rata-rata $27^{\circ} \mathrm{C}$. Adapun jenis tanaman yang dibudidayakan di sekitar area penelitian yaitu, singkong, timun, kangkung dan cabai.

Intensitas serangan serangga hama dalam penelitian ini dilihat dari kerusakan daun pada tanaman kacang panjang (Vigna sinensis L.) yang sebelumnya telah diberikan beberapa perlakuan dengan aplikasi insektisida nabati yang diperoleh dari kombinasi ekstrak daun tapak dara (Catharanthus roseus L.) dan daun jambu air Semarang (Syzygium samarangense (Blum.) Merr.\& Perry) varietas camplong. Ekstrak yang diaplikasikan pada beberapa sampel tanaman kacang panjang memiliki konsentrasi yang bervariasi, yaitu konsentrasi $25 \%$, 40\%, 55\% dan $70 \%$. 


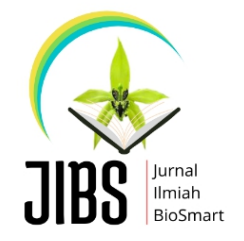

JURNAL ILMIAH BIOSMART (JIBS)

Volume 1, Nomor 1

p-ISSN: 2356-1823

https://jurnal.fkip.unmul.ac.id/index.php/biosmart

Selain itu dalam penelitian ini terdapat pula kontrol dimana terdapat beberapa sampel tanaman kacang panjang yang tidak diberikan kombinasi ekstrak daun tapak dara dan daun jambu air Semarang, hanya diberi air.

Berdasarkan hasil penelitian dan pengamatan intensitas serangan serangga hama pada tanaman kacang panjang dapat di sajikan pada gambar grafik berikut ini.

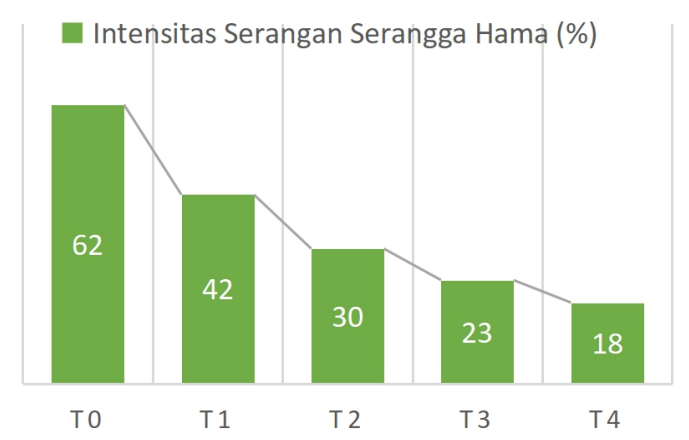

Gambar 1. Grafik Intensitas Serangan Serangga Hama Pada Tanaman Kacang Panjang 11 Hari Setelah Tanam.

Berdasarkan grafik intensitas serangan serangga hama pada tanaman kacang panjang 11 hari setelah tanam, serangan hama tertinggi terdapat pada perlakuan $T_{0}$ (kontrol) yaitu mencapai 62\%. Hal tersebut dikarenakan perlakuan $\mathrm{T}_{0}$ hanya menggunakan air saja (tidak menggunakan kombinasi ekstrak daun tapak dara dan daun jambu air Semarang). Sedangkan serangan hama terendah terdapat pada perlakuan $\mathrm{T}_{4}$ yaitu $18 \%$, hal ini dikarenakan perlakuan $\mathrm{T}_{4}$ menggunakan konsentrasi 70\% kombinasi ekstrak daun tapak dara dan daun jambu air Semarang. Rata-rata kerusakan yang terjadi akibat serangan serangga hama menyebabkan daun tanaman kacang panjang mejadi tidak sehat, meiliki bercak kuning dan berlubang.

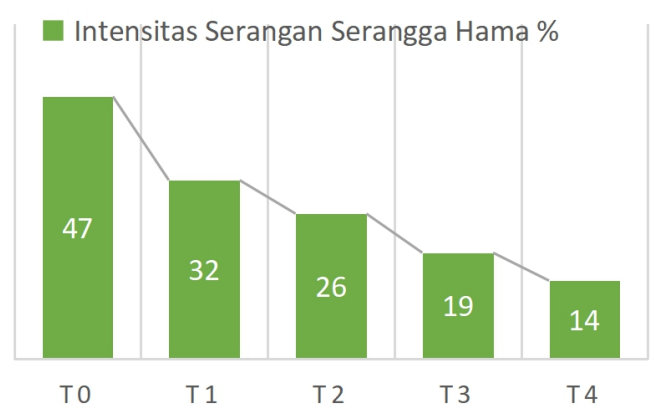

Gambar 2. Grafik Intensitas Serangan Serangga Hama Pada Tanaman Kacang Panjang 18 Hari Setelah Tanam. 


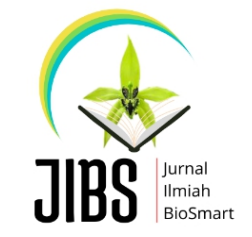

JURNAL ILMIAH BIOSMART (JIBS)

Volume 1, Nomor 1

p-ISSN: 2356-1823

https://jurnal.fkip.unmul.ac.id/index.php/biosmart

Berdasarkan grafik intensitas serangan serangga hama pada tanaman kacang panjang 18 hari setelah tanam, serangan hama tertinggi terdapat pada perlakuan $T_{0}$ (kontrol) yaitu mencapai $47 \%$. Hal tersebut dikarenakan perlakuan $\mathrm{T}_{0}$ hanya menggunakan air saja (tidak menggunakan kombinasi ekstrak daun tapak dara dan daun jambu air Semarang). Sedangkan serangan hama terendah terdapat pada perlakuan $\mathrm{T}_{4}$ yaitu $14 \%$, hal ini dikarenakan perlakuan $\mathrm{T}_{4}$ menggunakan konsentrasi 70\% kombinasi ekstrak daun tapak dara dan daun jambu air Semarang. Rata-rata kerusakan yang terjadi akibat serangan serangga hama menyebabkan daun tanaman kacang panjang mejadi tidak sehat, meiliki bercak kuning dan berlubang.

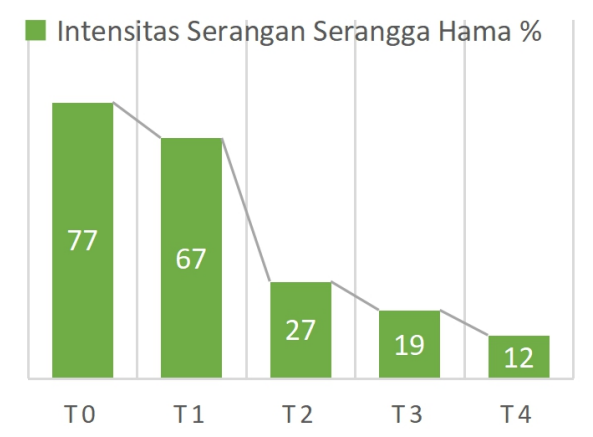

Gambar 3. Grafik Intensitas Serangan Serangga Hama Pada Tanaman Kacang Panjang 25 Hari Setelah Tanam.

Berdasarkan grafik intensitas serangan serangga hama pada tanaman kacang panjang 25 hari setelah tanam, serangan hama tertinggi terdapat pada perlakuan $\mathrm{T}_{0}$ (kontrol) yaitu mencapai $77 \%$. Hal tersebut dikarenakan perlakuan $\mathrm{T}_{0}$ hanya menggunakan air saja (tidak menggunakan kombinasi ekstrak daun tapak dara dan daun jambu air semarang). Sedangkan serangan hama terendah terdapat pada perlakuan $\mathrm{T}_{4}$ yaitu $12 \%$, hal ini dikarenakan perlakuan $\mathrm{T}_{4}$ menggunakan konsentrasi $70 \%$ kombinasi ekstrak daun tapak dara dan daun jambu air Semarang. Rata-rata kerusakan yang terjadi akibat serangan serangga hama menyebabkan daun tanaman kacang panjang mejadi tidak sehat, meiliki bercak kuning dan berlubang. 


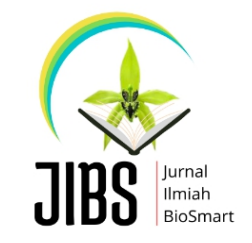

JURNAL ILMIAH BIOSMART (JIBS)

Volume 1, Nomor 1

p-ISSN: 2356-1823

https://jurnal.fkip.unmul.ac.id/index.php/biosmart

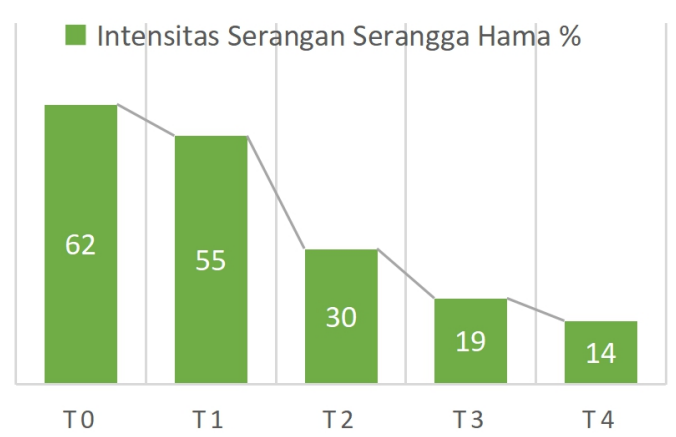

Gambar 4. Grafik Intensitas Serangan Serangga Hama Pada Tanaman Kacang Panjang 32 Hari Setelah Tanam.

Berdasarkan grafik intensitas serangan serangga hama pada tanaman kacang panjang 32 hari setelah tanam, serangan hama tertinggi terdapat pada perlakuan $T_{0}$ (kontrol) yaitu mencapai 62\%. Hal tersebut dikarenakan perlakuan $\mathrm{T}_{0}$ hanya menggunakan air saja (tidak menggunakan kombinasi ekstrak daun tapak dara dan daun jambu air semarang). Sedangkan serangan hama terendah terdapat pada perlakuan $\mathrm{T}_{4}$ yaitu 14\%, hal ini dikarenakan perlakuan $\mathrm{T}_{4}$ menggunakan konsentrasi 70\% kombinasi ekstrak daun tapak dara dan daun jambu air Semarang. Rata-rata kerusakan yang terjadi akibat serangan serangga hama menyebabkan daun tanaman kacang panjang mejadi tidak sehat, meiliki bercak kuning dan berlubang.

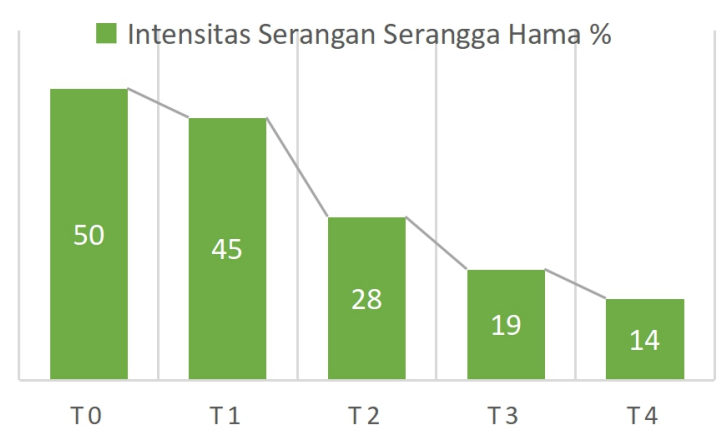

Gambar 5. Grafik Intensitas Serangan Serangga Hama Pada Tanaman Kacang Panjang 39 Hari Setelah Tanam.

Berdasarkan grafik intensitas serangan serangga hama pada tanaman kacang panjang 39 hari setelah tanam, serangan hama tertinggi terdapat pada perlakuan $T_{0}$ (kontrol) yaitu mencapai 50\%. Hal tersebut dikarenakan perlakuan $\mathrm{T}_{0}$ hanya menggunakan air saja (tidak menggunakan kombinasi ekstrak daun tapak dara dan daun jambu air semarang). Sedangkan serangan hama terendah terdapat pada 


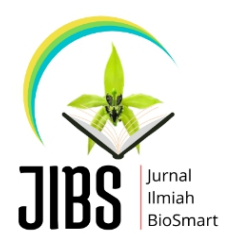

JURNAL ILMIAH BIOSMART (JIBS)

Volume 1, Nomor 1

p-ISSN: 2356-1823

https://jurnal.fkip.unmul.ac.id/index.php/biosmart

perlakuan $\mathrm{T}_{4}$ yaitu $14 \%$, hal ini dikarenakan perlakuan $\mathrm{T}_{4}$ menggunakan konsentrasi $70 \%$ kombinasi ekstrak daun tapak dara dan daun jambu air Semarang. Rata-rata kerusakan yang terjadi akibat serangan serangga hama menyebabkan daun tanaman kacang panjang mejadi tidak sehat, meiliki bercak kuning dan berlubang.

Dalam penelitian ini ditemukan pula beberapa jensi serangga hama yang menyerang tanaman kacang panjang yaitu kutu daun (Aphis sp), lalat kacang (Ophiomyia phaseoli) dan kepik hitam (Paraeucosmetus pallicornis).

Penelitian ini dilakukan selama 3 bulan terhitung dari bulan Juli hingga September 2020 mulai dari observasi, studi literatur, penelitian dna tahap pengusunan laporan. Penelitian ini bertujuan untuk mengetahui pengaruh kombinasi ekstrak daun tapak dara (Catharanthus roseus L.) dan daun jambu air Semarang (Syzygium samarangense (Blum.) Merr.\& Perry) varietas camplong terhadap intensitas serangan serangga hama tanaman kacang panjang (Vigna sinensis L.). hasil penelitian menunjukkan bahwa serangan serangga hama pada tanaman kacang panjang yang diberikan perlakuan dengan aplikasi pestisida nabati dari ekstrak kombinasi daun tapak dara dan daun jambu air Semarang lebih sedikit dibandingkan dengan tanaman kacang panjang yang tidak diberikan pestisida nabati dari kombinasi ekstrak daun tapak dara dan daun jambu air Semarang. Hal ini membuktikan bahwa daun tapak dara dan daun jambu air Semarang memiliki zat aktif berupa alkaloid, terpenoid, fenol, tanin, saponin, quinin, dan sterol yang dapat dijadikan sebagai pestisida nabati.

Kandungan dari senyawa bioaktif seperti alkaloid, tanin, terpenoid, fenol, flavonoid, quinin, sterol dan saponin yang terdapat pada kedua daun tersebut bersifat toksik sehingga hama akan menghindari tanaman tersebut atau dapat mati perlahan karena telah memakan bagian dari tanaman yang mengandung senyawa bioaktif tersebut.

Hal ini sesuai dengan teori Soemirat dalam Aseptianova, dkk (2017) senyawa alkaloid bersifat racun mampu menghambat kerja pada sistem saraf dan merusak membran sel. Efek yang ditimbulkan akan menghambat proses transmisi saraf. Efek lain yang ditimbulkan adalah proses inhibitor sintesis kitin dan kerja hormon yang terhambat, Mokodompit, dkk (2013) juga menyatakan bahwa alkaloid dan flavonoid 


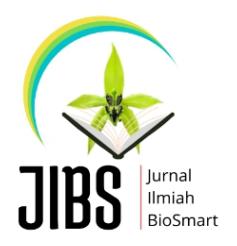

JURNAL ILMIAH BIOSMART (JIBS)

Volume 1, Nomor 1

p-ISSN: 2356-1823

https://jurnal.fkip.unmul.ac.id/index.php/biosmart

merupakan senyawa yang dapat bertindak sebagai stomach poisoning atau racun perut, sehingga apabila senyawa alkaloid dan flavonoid masuk kedalam tubuh serangga maka alat pencernaannya akan terganggu, senyawa tersebut juga mampu menghambat reseptor perasa pada daerah mulut serangga, sehingga menyebabkan serangga tidak mampu mengenali makanannya hingga mati kelaparan.

Tanin dapat menurunkan aktivitas enzim pencernaan (protease dan amilase) dan mengganggu aktivitas protein usus, sehingga akan mengalami gangguan nutrisi (Aseptianova, dkk, 2017). Terpenoid bersifat sebagai penolak serangga (repellent) karena memiliki bau menyengat yang tidak disukai serangga. Senyawa ini dapat mempengaruhi fungsi saraf dan menghambat enzim asetilkolinesterase (AchE) yang menyebabkan gangguan transmisi rangsang, menurunkan kerja otot, dan kematian pada serangga (Purwatiningsih, dkk, 2019). Aseptianova, dkk (2017) berpendapat bahwa senyawa flavonoid akan merusak permeabilitas dinding sel dan menghambat kerja enzim sehingga mempengaruhi proses metabolisme pada serangga. Senyawa kuinon dapat menghambat pengkonsumsian makan serta menghambat pertumbuhan serangga. Senyawa kuinon dapat bersifat toksik dengan cara mengganggu regulasi Ca2+ dalam tubuh (Chen dalam Mulyana, 2002). Senyawa steroid merupakan senyawa yang memiliki sifat toksik terhadap serangga. Menurut Harborne dalam Rohananto (2013) senyawa saponin ini digunakan untuk pembasmi hama tertentu dan bersifat racun bagi binatang berdarah dingin. Sifat-sifat saponin yaitu berasa pahit, berbusa dalam air, mempunyai sifat detergen yang baik dan anti eksudatif. Saponin mempunyai aktivitas dapat menghemolisis sel darah merah dan anti inflamasi, hal ini sejalan dengan teori dari Hildamamus dalam Liem (2013) saponin dapat merusak mukosa kulit jika terabsorbsi dan akan mengakibatkan hemolisis sel darah sehingga pernapasan menjadi terhambat dan dapat mengakibatkan kematian.

Dalam penelitian ini kombinasi ekstrak daun tapak dara dan daun jambu air Semarang yang dijadikan sebagai pestisida nabati diperoleh dengan cara mengekstrak daun tapak dara dan daun jambu air Semarang yang telah diolah. Proses pengolahan kombinasi eksttrak daun tapak dara dan daun jambu air 
Semarang dilakukan dengan cara sederhana, yaitu dengan cara menghaluskan semua bahan dengan di blender dan kemudian dimaserasi selama 24 jam.

Bahan dan cara yang digunakan dalam pembuatan kombinasi ekstrak daun tapak dara dan daun jambu air Semarang inipun sangat sederhana, hanya diperlukan daun tapak darah dan daun jambu air Semarang yang telah di timbang masingmasing 250 gram, air dan deterjen. Dalam hal ini pembuatan pestisida nabati pelarut yang digunakan adalah air dan deterjen, hal ini disebabkan karena deterjen dapat berfungsi sebagai perekat zat yang terkandung dalam kombinasi ekstrak daun tapak dara dan daun jambu air Semarang yang diapliaksikan lebih tahan merekat pada tanaman.

Dalam penelitian ini, kombinasi ekstrak daun tapak dara dan daun jambu Air seamrang yang telah di haluskan dan dimaserasi selama 24 jam kemudian di encerkan dengan konsentrasi $25 \%$, 40\%, 55\% dan diaplikasikan pada sampel kacang panjang. Pengaplikasian kombinasi ekstrak daun tapak dara dan daun jambu air Semarang dilakukan setiap 2 kali seminggu pada sore hari (pukul 16.00-17.00 Wita).

Berdasarkan hasil analisis sidik ragam pada 11 HST menunjukkan nilai $F_{\text {hitung }}$ $(187,74)>F_{\text {tabel }}(4.77)$ pada taraf signifikan 1\%, pada $18 \mathrm{HST}$ menunjukkan nilai $F_{\text {hitung }}$ $(118,58)>F_{\text {tabel }}(4.77)$ pada taraf signifikan 1\%, pada 25 HST menunjukkan nilai $F_{\text {hitung }}$ $(476,7)>F_{\text {tabel }}(4.77)$ pada taraf signifikan 1\%, pada 32 HST menunjukkan nilai $F_{\text {hitung }}$ $(271,00)>F_{\text {tabel }}(4.77)$ pada taraf signifikan $1 \%$ dan pada 39 HST menunjukkan nilai $F_{\text {hitung }}(271,00)>F_{\text {tabel }}(4.77)$ pada taraf signifikan $1 \%$.

Berdasarkan data tersebut menunjukkan bahwa semakin tinggi tingkat kombinasi ekstrak daun tapak dara dan daun jambu air Semarang ,maka semakin rendah intensitas serangan serangga hama pada tanaman kacnag panjang. Selama penelitian kerusakan tanaman kacang panjang tampak dari banyaknya lubanglubang dan bercak-bercak warna kuning dari daun kacang panjang tersebut. Rusaknya daun secara umum disebabkan akibat pola makan hama tanaman pada tanaman khususnya pada daun, baik berupa gigitan daun secara langsung, tusukan atau sayatan bahkan akibat penghisapan cairan pada tanaman tersbut. Selain itu disebakan juga karena penumpukan telur atau larva pada daun tanaman kacnag panjang. 


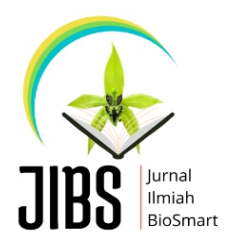

JURNAL ILMIAH BIOSMART (JIBS)

Volume 1, Nomor 1

p-ISSN: 2356-1823

https://jurnal.fkip.unmul.ac.id/index.php/biosmart

\section{KESIMPULAN}

Berdasarkan penelitian dan analisis data yang telah dilakukan, maka dapat disimpulkan bahwa terdapat pengaruh pemberian kombinasi ekstrak daun tapak dara (Catharanthus roseus L.) dan daun jambu air Semarang (Syzygium samarangense (Blum.) Merr.\& Perry) varietas camplong sebagai pestisida nabati terhadap intensitas serangan serangga hama pada tanaman kacang panjang (Vigna sinensis L.).

Konsentrasi kombinasi ekstrak daun tapak dara (Catharanthus roseus L.) dan daun jambu air Semarang (Syzygium samarangense (Blum.) Merr.\& Perry) varietas camplong yang terbaik untuk dijadikan insektisida nabati pada tanaman kacang panjang (Vigna sinensis L) adalah konsentrasi T4 (70\%).

\section{REFERENCES / REFERENSI}

Agustina, Eva; dkk. 2018. Identifikasi Senyawa Aktif dari Daun Jambu air semarang (Sygyzium aqueum) dengan Perbandingan Beberapa Pelarut Pada Metode Maserasi. BIOTROPIC The Journal of Tropical Biology. 2 (2): 109

Apriliyanto, Eko dan Bondan H. S. 2014. Perkembangan Hama dan Musuh Alamai Pada Tumpangsari Tanaman Kacang Panjang dan Pakcoy. AGRITECTH. 16 (2): 98

Aseptianova, dkk. 2017. Efektifitas Pemanfaatan Tanaman Sebagai Insektisida Elektrik Untuk Mengendalikan Nyamuk Penular Penyakit DBD. Bioeksperimen: Jurnal Penelitian Biologi. 3 (2): 15-16

Badan Pusat Statistik Kabupaten Nunukan. 2018. Statistik Sayur-Sayuran dan BuahBuahan Kabupaten Nunukan 2018. Badan Pusat Statistik Kabupaten Nunukan: Nunukan

Baon, Yosep Karolus Pati. 2017. Pengaruh Pemberian pupuk Organik Cair Limbah Ikan Nila (Oreochormis niloticus)Terhadap Pertumbuhan dan Produksi Tanaman Kacang Panjang (Vigna sinensis L.). Skripsi: Fakultas Keguruan dan IImu Pendidikan, Universitas Sanata Dharma: Yogyakarta

Fajar, Ahmad Khamid. 2016. Uji Potensi Antikanker Pada Ekstrak Air Daun Jambu air semarang (Syzygium samarangse (BL.)Merrill dan Perry Varietas Deli Hijau Dengan Metode Brine Shrimp Lethality Test (BSLT). Skripsi: Fakultas Sains dan Teknologi, Universitas Islam Negeri Walisongo: Semarang 


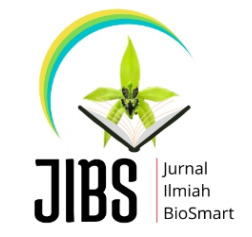

JURNAL ILMIAH BIOSMART (JIBS)

Volume 1, Nomor 1

p-ISSN: 2356-1823

https://jurnal.fkip.unmul.ac.id/index.php/biosmart

Glio, M. Tosin. 2015. Pupuk Organik \& Pestisida Nabati No. 1 ala Tosin Glio. Jakarta: Agro Media Pustaka.

Mulyana. 2002. Ekstraksi Senyawa Aktif Alkaloid, Kuinon, dan Saponin Dari Tumbuhan Kecubung Sebagai Larvasida dan Insektisida Terhadap Nyamuk Aedes aegypti. Skripsi: Fakultas Matematika dan Ilmu Pengetahuan Alam, Institut Pertanian Bogor: Bogor.

Purwatinigsih, dkk. 2019. Toksisitas Ekstrak N-Heksana Serbuk Gergaji Segon (Albizia falcataria L. Forberg) Terhadap Moralitas Serangga Penggerek Buah Kopi (Hypothenemus hampei Ferr.) (Scolytidae: Coleoptera). BIOTROPIC The Journal of Tropical Biology. 3 (1): 44-45

Putri, Fitri Mulia, dkk. 2015. Uji Mutu Hasil Produksi Kacang Panjang (Vigna sinensis L.). Jurnal Agrotek Tropika. 3 (3):317.

Rohananto, Rofindra. 2013. Efektivitas Ekstrak Daun Tapak Dara (Cahranthus roseus) Sebagai Lavrvasida Nyamuk Culex quiquefasciatus. Skripsi: Fakultas Kedokteran Hewan, Institut Pertanian Bogor: Bogor

Rukmana, Rahmat. 2014. Sukses Budidaya aneka kacang sayur di perkarangan \& perkebunan. Yogyakarta: Lily Publisher 